\title{
Granulomatous appendicitis: a perioperative challenge
}

\author{
Nicola Colucci 자 , ${ }^{1,2}$ Jérémy Meyer, ${ }_{1}^{1}$ Giacomo Puppa, ${ }^{3}$ Christian Toso ${ }^{1}$
}

${ }^{1}$ Department of Surgery, Division of Digestive Surgery, Geneva University Hospitals, Geneva, Switzerland

${ }^{2}$ Department of Clinical-Surgical, Diagnostic and Pediatric

Sciences, University of Pavia,

Pavia, Italy

${ }^{3}$ Department of Clinical

Pathology, Geneva University Hospitals, Geneva, Switzerland

Correspondence to

Dr Nicola Colucci;

n.colucci@outlook.it

Accepted 16 September 2020

Check for updates

(c) BMJ Publishing Group Limited 2020. No commercial re-use. See rights and permissions. Published by BMJ.

To cite: Colucci N, Meyer J, Puppa G, et al. BMJ Case Rep 2020;13:e238955. doi:10.1136/bcr-2020238955

\section{DESCRIPTION}

A 24-year-old healthy man presented with acute abdominal pain localised to the right iliac fossa since 24 hours. Rebound tenderness was present in the right lower quadrant. Blood tests showed a mild elevation of $\mathrm{C}$-reactive protein $(26.5 \mathrm{mg} / \mathrm{L})$ and a normochromic normocytic anaemia (haemoglobin level of $121 \mathrm{~g} / \mathrm{L}$ ). CT scan revealed a fluid-filled, dilated appendix. Indication for laparoscopic appendectomy was given. Intraoperative semiology was evocative of a mucocele, and a mucoid-like plug was found on the appendiceal serosa (figure 1). An appendectomy with complete mesoappendix resection and caecal fundus stapling was therefore performed. No other pathological findings were found during laparoscopy. Histological analysis did not find any mucoid lesion but showed an acute on chronic granulomatous appendicitis, with transmural, Crohn-like inflammation (figure 2). Granulomas were non-necrotic, and consisted of epithelioid and multinucleated giant cells, distributed from mucosa to subserosa (figure 3 ). The perioperative hypothesis of a mucinous epithelial neoplasm was discarded: moreover, the peritoneal lavage cytological examination was negative. The postoperative period was uneventful and the patient returned to full duty 2 weeks after surgery. He underwent an ileocolonoscopy on postoperative week 6 , which was unremarkable, and he was doing well 6 months later.

According to geographic areas, acute granulomatous appendix is found in $0.14 \%-2.3 \%$ of all appendectomies. ${ }^{1}$ In case of transmural granulomatous inflammation, the perioperative presentation can mimic an appendiceal mucinous neoplasm. In case of doubt, a caecal wedge resection appendectomy with complete mesoappendix resection should be performed, by strictly avoiding to perforate the suspected mucocele. ${ }^{2}$

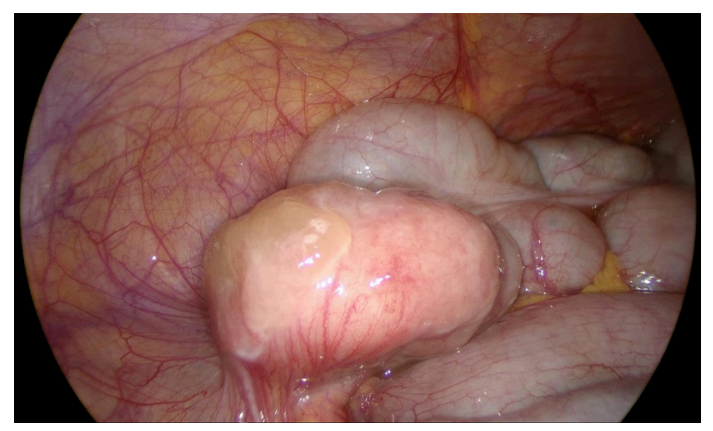

Figure 1 Laparoscopy showing a dilated appendix with a mucoid-like plug on the appendiceal serosa.

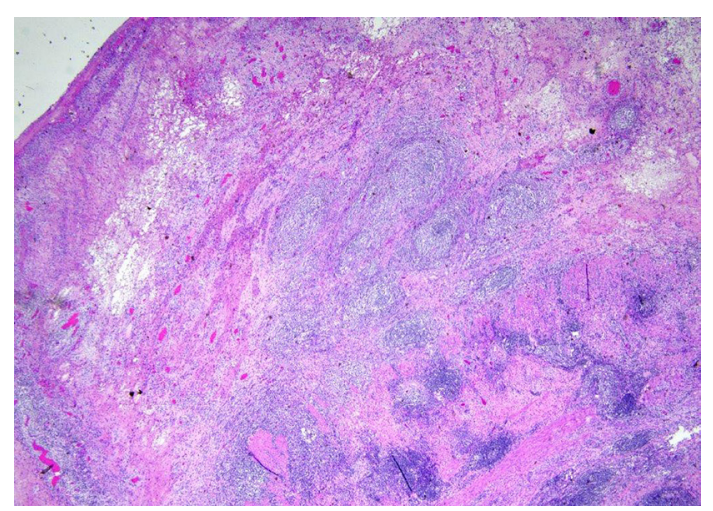

Figure 2 Subserosal layer of the appendix wall expanded by a heavy edematous, suppurative and fibrinous inflammation.

The main aetiologies of granulomatous appendicitis are infectious (Yersinia pseudotuberculosis, Mycobacterium tuberculosis, fungi and parasites), inflammatory (foreign bodies reaction), mechanical (obstruction secondary to a faecal stone, a mucocele or an appendix tumour) or related to systemic conditions (Crohn's disease and sarcoidosis). ${ }^{3}$ Delayed appendectomy performed after conservative management of a perforated appendicitis is also related to marked granulomatous features, with a Crohn-like transmural inflammation pattern. Interestingly, this pathologic aspect is rare in acute appendectomies. ${ }^{4}$ Although it is possible to find in the literature several cases of granulomatous appendicitis attributed to Crohn's disease, the clinical course is generally favourable and could suggests of a distinct nosological entity. ${ }^{5}$ Nevertheless, ileocolonoscopy should be performed to rule out Crohn's disease in patients complaining of suggestive clinical clues

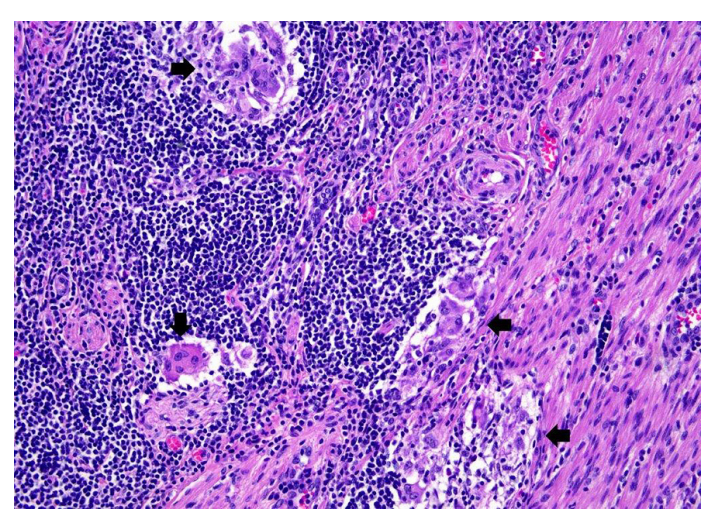

Figure 3 Several non-necrotic granulomas, made of epithelioid and multinucleated giant cells (black arrows). 


\section{Patient's perspective}

The intervention went well, and I was happy to restart biking and doing my physical routine 2 weeks later. I was initially concerned by the idea of being affected by a cancer, because this possibility was raised by the surgeons in response to the presence of mucus around my appendix. Then, the pathology report showed a 'granulomatous appendicitis'. Even if I was explained of the potential connection to Crohn's disease, I was feeling great and such an eventuality seemed improbable to me. The colonoscopy confirmed that there was nothing to worry about, but I am clearly aware of the importance of being followed-up. I am glad to share my case, in order to sensibilise surgeons about this rare condition.

\section{Learning points}

- Granulomatous appendicitis is a rare presentation of a common condition that could mimic perioperatively appendiceal mucinous neoplasm.

- Patients diagnosed with granulomatous appendicitis presenting Crohn-like features should undergo a systematic ileocolonoscopy to rule out Crohn's disease. or presenting Crohn-like features on pathology. In patients otherwise asymptomatic or with no Crohn-like lesions, a clinical follow-up may be sufficient.

Contributors NC and JM performed the surgery, conceived the study and wrote the manuscript. GP performed pathological assessment, took histology slide pictures and helped writing the manuscript. CT provided critical intellectual input in conceiving and finalising the manuscript.

Funding The authors have not declared a specific grant for this research from any funding agency in the public, commercial or not-for-profit sectors.

Competing interests None declared.

Patient consent for publication Obtained.

Provenance and peer review Not commissioned; externally peer reviewed.

\section{ORCID iD}

Nicola Colucci http://orcid.org/0000-0003-4939-981X

\section{REFERENCES}

1 Blair NP, Bugis SP, Turner LJ, et al. Review of the pathologic diagnoses of 2,216 appendectomy specimens. Am J Surg 1993;165:618-20.

2 Meyer J, Balaphas A, Koessler T, et al. Les tumeurs de I'appendice et leur prise en charge [Appendix tumours and their management]. Rev Med Suisse 2018;14:1225-9.

3 Mizushima T, Ito T, Mizuno H, et al. Idiopathic granulomatous appendicitis treated surgically with long-term follow-up: report of a case. Surg Today 2007:37:690-3.

4 Guo G, Greenson JK. Histopathology of interval (delayed) appendectomy specimens: strong association with granulomatous and xanthogranulomatous appendicitis. Am J Surg Pathol 2003;27:1147-51.

5 Higgins MJ, Walsh M, Kennedy SM, et al. Granulomatous appendicitis revisited: report of a case. Dig Surg 2001;18:245-8.

Copyright 2020 BMJ Publishing Group. All rights reserved. For permission to reuse any of this content visit

https://www.bmj.com/company/products-services/rights-and-licensing/permissions/

BMJ Case Report Fellows may re-use this article for personal use and teaching without any further permission.

Become a Fellow of BMJ Case Reports today and you can:

- Submit as many cases as you like

- Enjoy fast sympathetic peer review and rapid publication of accepted articles

- Access all the published articles

Re-use any of the published material for personal use and teaching without further permission

Customer Service

If you have any further queries about your subscription, please contact our customer services team on +44 (0) 2071111105 or via email at support@bmj.com.

Visit casereports.bmj.com for more articles like this and to become a Fellow 